\title{
Penelantaran Anak Ditinjau dalam Hukum Islam dan Undang-Undang Nomor 39 Tahun 1999 tentang Hak Asasi Manusia
}

\author{
${ }^{1}$ Rudi Wahyu Suharto, ${ }^{1}$ Abdur Rahim ${ }^{2}$ \\ Institut Agama Islam Al-Zaytun Indonesia \\ doi) https://doi.org/10.32507/mizan.v4i1.607
}

\begin{abstract}
Abandonment of children by parents is an act that violates the prevailing legal norms. The actions carried out in regard to the unmet fulfillment of children's needs properly, physically, mentally, spiritually and socially. Abandonment of children causes detrimental effects, such as problems with cognitive, social and emotional development, drug use, self-injury, lower social abilities, mental and neurological problems. The method used in this study is qualitative research from a review of Islamic laws and positive law No. 39 of 1999 concerning human rights The type of research used is the library (research library). The research approach uses the views and doctrines that develop in the science of law (conceptual approaches) taken from literature that support and are relevant to the title of the tesis. The results showed that the phenomenon of neglect is still found in people's lives, due to lack of sufficient economy or other things so that parents neglect their responsibilities. Abandonment of children in human rights review is the worst form of violation, in the form of legal protection by the State to children in fact already exists in the act. But no less important is the role of parents and society in shaping the mental and moral of the child to continue to guide the child's growth.
\end{abstract}

Keywords: Abandonment of children, Economy, Protection.

\begin{abstract}
Abstrak
Penelantaran anak yang dilakukan oleh orang tua merupakan suatu perbuatan yang melanggar norma hukum. Perbuatan yang dilakukan yakni berkenaan dengan tidak bisa terpenuhinya kebutuhan anak secara wajar, baik fisik, mental, spiritual maupun sosial. Penelantaran anak menyebabkan efek yang merugikan, seperti masalah dengan perkembangan kognitif, sosial dan emosional, penggunaan narkoba, melukai diri sendiri, kemampuan hidup sosial yang lebih rendah, masalah kejiwaan dan neurologis. Metode yang digunakan dalam penelitian ini adalah penelitian kualitatif dari tinjauan Hukum Islam dan hukum positif pada Undang-undang No. 39 Tahun 1999 tentang Hak Asasi Manusia (HAM). Jenis penelitian yang digunakan adalah kepustakaan (library research). Pendekatan penelitian menggunakan pandangan dan doktrin yang berkembang di dalam ilmu hukum (conceptual approaches) yang diambil dari literatur yang relevan. Hasil penelitian menunjukkan bahwa fenomena penelantaran masih ditemui dalam kehidupan masyarakat, karena faktor ekonomi orang tua, sehingga orang tua lalai dengan tanggungjawabnya. Penelantaran anak dalam tinjauan HAM merupakan bentuk pelanggaran terburuk. Walaupun hak seorang sudah dilindungi oleh hukum, namun peran orang tua dan masyarakat tidak kalah penting dalam membentuk mental dan moral anak untuk terus membimbing anak sampai tumbuh kembang dewasa.
\end{abstract}

Kata Kunci: Penelantaran Anak, Ekonomi, Perlindungan Maret 2020.

* Naskah diterima tanggal: 12 Januari 2020, direvisi: 15 Februari 2020, disetujui untuk terbit: 2

${ }^{1}$ Rudi Wahyu Suharto adalah Peneliti di Institut Agama Islam Al Zaytun Indonesia. Mekarjaya, Gantar, Indramayu, Jawa Barat. E-mail: raider2829@gmail.com.

${ }^{2}$ Abdur Rahim adalah Dosen di Institut Agama Islam Al Zaytun Indonesia. Mekarjaya, Gantar, Indramayu, Jawa Barat. E-mail: abdur.rahim@iai-alzaytun.ac.id. 


\section{A. PENDAHULUAN}

Penelantaran anak merupakan suatu perbuatan yang melanggar norma hukum yang berlaku yang dilakukan oleh orang tua, dalam kategori tidak bisa memenuhi kebutuhan anak secara wajar, baik fisik, mental, spiritual maupun sosial. Kepentingan anak harus dijadikan dasar pedoman oleh mereka yang bertanggung jawab terhadap pendidikan dan bimbingan anak yang bersangkutan. Tanggungjawab ini adalah hal yang primer yang harus dilakukan oleh orang tua. Anak-anak harus mempunyai kesempatan yang leluasa untuk bermain dan berekreasi yang harus diarahkan untuk tujuan pendidikan, dan masyarakat serta penguasa yang berwenang harus berusaha meningkatkan pelaksanaan hak tersebut. ${ }^{3}$

Setiap anak berhak tumbuh kembang sesuai minat dan bakatnya, kemudian orang tua memiliki tanggung jawab penuh terhadap perkembangan anaknya hingga tumbuh dewasa. Tanggung jawab ini merupakan kewajiban penuh orang tua untuk melaksanakan dengan baik untuk masa depan anak-anaknya. Sehingga menghasilkan generasi penerus bangsa yang mempunyai kualitas akhlak yang baik.

Tidak ada penegakan hukum yang serius terhadap orang tua yang melakukan tindakan penelantaran terhadap anaknya. Seorang anak mengharapkan bisa memiliki ruang untuk melakukan kegiatan bermain, belajar dan mengembangkan minat serta bakatnya untuk masa depan. Namun realitanya, justru dunia anak masih diwarnai data kelam dan menyedihkan. Anak Indonesia masih terus mengalami kekerasan, secara kebudayaan mereka masih berada di tengah situasi yang tidak diinginkan. Modernisasi di negeri ini belum memperhatikan persoalan anak dengan baik, justru yang terjadi mereka menjadi korban dari modernitas yang tengah berlangsung. ${ }^{4}$

Hukum Islam sebagai salah satu sistem hukum yang berlaku di Indonesia mempunyai kedudukan dan arti yang sangat penting dalam rangka pelaksanaan pembangunan manusia seutuhnya, yakni baik pembangunan dunia maupun pembangunan akhirat, dan baik di bidang materil, maupun di bidang mental spiritual. Dalam berbagai ayat Al-Qur'an dan hadits dapat ditemui bahwa agama Islam menghendaki agar pembangunan itu dilaksanakan, baik pembangunan manusia sebagai individu, maupun manusia sebagai masyarakat, baik dalam bidang materil, maupun dalam bidang spiritual.

Dalam pembangunan bidang mental spiritual, hukum Islam berusaha menjadikan setiap individu sebagai insan kamil (manusia paripurna) yakni manusia yang berakidah yang baik, benar, luhur, dan beramal shaleh. Dalam bidang materil, hukum Islam meletakkan prinsip-prinsip atau dasar-dasar umum yang dengan itu pengelolaan dan pemanfaatan materi terjamin untuk manusia berdasarkan ridha Allah SWT. Selanjutnya dalam pembangunan bidang sosial, hukum Islam meletakkan prinsip-prinsip seperti prinsip persamaan, persatuan, persaudaraan, keadilan,

\footnotetext{
3 Abdul hakim Garuda Nusantara, Makalah."Prospek Perlindungan Anak" (Jakarta: Seminar Perlindungan Hak-hak Anak, 1986), hal. 19.

${ }^{4}$ Abu Huraerah, Kekerasan Anak Terhadap Anak (Bandung: Nuansa, 2006), hal.15.
} 
permusyawaratan, keseimbangan dan lain-lain yang dengan prinsip-prinsip tersebut terjamin kemajuan dan perkembangan sosial secara bertahap dan mantap. ${ }^{5}$

Penelantaran anak menyebabkan efek yang merugikan, seperti masalah dengan perkembangan kognitif, sosial dan emosional, penggunaan narkoba, melukai diri sendiri, kemampuan hidup sosial yang lebih rendah, masalah kejiwaan dan neurologis, kesinambungan pengabaian terhadap anak-anak mereka sendiri dan potensi ingin membalas dendam pada orang-orang yang mengabaikan mereka.

\section{B. METODE PENELITIAN}

Metode yang digunakan dalam penelitian ini adalah penelitian kualitatif. Jenis penelitian yang digunakan adalah kepustakaan (library research). Pendekatan penelitian ini menggunakan pandangan dan doktrin yang berkembang di dalam ilmu hukum (conceptual approaches). Data penelitian diambil dari literatur baik dari buku ataupun sumber yang mendukung dan relevan dengan penelitian ini.

\section{ANALISIS DAN PEMBAHASAN}

\section{Telaah Hukum Islam Terhadap Penelantaran Anak}

Di dalam Al-Qur'an dijelaskan bahwa asal-usul seorang anak yaitu melalui sebuah pernikahan yang sah, suami istri saling berjanji membentuk suatu keluarga yang baik sakinah, mawadah dan warohmah. Kemudian setelah terbentuknya keluarga yang baik, penuh kasih sayang dan rahmat, mulailah Allah menitipkan amanat kepada pasangan suami istri dengan di karuniai keturunan untuk masa depan yaitu seorang anak yang menjadi buah hatinya.

Anak adalah sebuah perhiasan dunia yang dilahirkan oleh orang tuanya, sebagaimana Allah SWT berfirman dalam surat Al-Kahfi ayat 46: "Harta dan anak-anak adalah perhiasan kehidupan dunia tetapi amalan-amalan yang kekal lagi saleh adalah lebih baik pahalanya di sisi Tuhanmu serta lebih baik untuk menjadi harapan."

Ayat di atas mengingatkan manusia agar senantiasa memelihara dan menjaga diri serta keluarga dari bahaya dan ancaman api neraka. Oleh karena itu arahan orang tua harus jelas, di samping keteladanan yang mendorong setiap anggota keluarga untuk memiliki pribadi yang kuat, bersikap disiplin, memiliki pola hidup yang benar, sesuai petunjuk agama. Dan orang tua wajib menyediakan sarana dan perlengkapan untuk dapat berlangsungnya pembinaan dan pendidikan dalam keluarga seperti tempat ibadah, belajar membaca Al-Qur'an alat tulis belajar, buku-buku, alat belajar modern seperti komputer dan lainnya.

Anak adalah suatu karunia yang diberikan Allah SWT pada hambanya. Penelantaran anak dengan alasan apapun adalah hal yang dilarang, baik itu secara agama maupun secara hukum yang berlaku di negara. Dalam QS. At-Tahrim ayat 6,

\footnotetext{
${ }^{5}$ M. Arifin Hamid, Hukum Islam Perspektif Keindonesiaan (Sebuah Pengantar Dalam Memahami Realitasnya di Indonesia) (Makasar: PT. Umitoha Ukhuwah Grafika, 2011), hal. 270.
} 
Allah SWT berfirman yang artinya: "Hai orang-orang yang beriman, peliharalah dirimu dan keluargamu ke dalam api neraka."

Setiap orang tua mempunyai 3 (tiga) peran terhadap anak yaitu merawat tumbuh kembang anak, membantu anak dalam menyesuaikan diri dengan lingkungannya serta merawat psikologis dan emosional anak. Dalam QS. An Nisa ayat 9 menjelaskan bahwa Islam sangat melarang penelantaran anak. Sebab seorang anak akan mewarisi segala hal yang dimiliki orang tua, menjaga keturunan keluarga serta harapan agama dan bangsa di masa depan.

Orang tua berkewajiban menjaga, mendidik dan memelihara agar anak dapat memajukan dan memperjuangkan agama dan bangsa dengan baik bukan malah menelantarkannya. Anak yang ditelantarkan akan menjadi pengemis, gelandangan, pengangguran yang berdampak pada kenakalan remaja. Perkembangan fisik dan emosional pun menjadi tidak normal, anak mengalami gangguan bahasa dan sosial.

Jika memang seorang ayah yang telah bekerja tidak mencukupi kebutuhan si anak, maka ayah boleh meminta bantuan ahli waris anak karena ahli waris berkewajiban menafkahi si anak sesuai dengan firman Allah QS. Al-Baqarah ayat 233. Waris adalah siapa pun yang akan mendapat warisan jika si anak telah meninggal. Jika si anak adalah orang dewasa, maka yang menjadi ahli waris adalah 15 pria dan 10 wanita. Jika si anak belum dewasa, maka ahli waris selain ayahnya adalah 3 pria yaitu kakek dari bapak, paman si anak atau paman sebapak dan 3 wanita yaitu ibu si anak, nenek dari pihak ibu anak atau nenek dari pihak ayah anak.

\section{Telaah Undang-undang No. 39 Tahun 1999 Tentang HAM Terhadap Penelantaran Anak}

Manusia memiliki perbedaan penting dibandingkan makhluk lain, seperti binatang. Perbedaan itu tak sekedar perbedaan semata, tetapi membawa konsekuensi bahwa manusia harus mendapatkan perlakuan yang berbeda dengan hewan. Prinsip ini tentu saja membawa konsekuensi lain, sebab untuk mewujudkan nilai kemanusiaan sebagai manifestasi (menjunjung tinggi martabat manusia) dibutuhkan sejumlah syarat agar bisa dijalankan. ${ }^{6}$

Yang menjadi masalah adalah bahwa dalam kenyataan hidup manusia terdapat begitu banyak kejadian yang bukan menjadi unsur penguat (yang mengukuhkan) keberadaan manusia dan kemanusiaan, tetapi masih menjadi peristiwa strategis bahwa manusia dianiaya, didera derita paksa, dirampas kehidupannya (dibunuh), dan dijegal setiap usaha untuk memenuhi kebutuhan hidupnya. Berbagai bentrokan, perang perebutan daerah, sampai usaha untuk mendapatkan keadilan telah memberikan kesaksian tentang bagaimana nyawa manusia melayang tanpa arti.

Adanya ajaran tentang Hak Asasi Manusia (HAM) dalam Islam menunjukan bahwa Islam sebagai agama telah memposisikan manusia sebagai makhluk terhormat

6 Wibawanto, A.. Jalan Kemanusian: Panduan untuk Memperkuat Hak Asasi Manusia. (Yogyakarta: Lapera Pustaka Utama, 1999). 
dan mulia. Oleh karena itu, perlindungan dan penghormatan terhadap manusia merupakan tuntutan ajaran itu sendiri yang wajib dilaksanakan oleh umatnya terhadap sesama manusia tanpa terkecuali. Seluruh hak yang diberikan Allah SWT itu bersifat tetap, kekal dan abadi, tidak boleh dirubah atau dimodifikasi.

Dalam Islam terdapat dua konsep tentang hak, yakni hak manusia (hak al-insan) dan hak Allah. Setiap hak itu saling melandasi satu sama lain. Hak Allah melandasi manusia dan juga sebaliknya. Dalam aplikasinya, tidak ada satu pun hak yang terlepas dari kedua hak tersebut, misalnya shalat. Sementara dalam hal urusan duniawi seperti hak kepemilikan, setiap manusia berhak untuk mengelola harta yang dimilikinya. Konsep Islam mengenai kehidupan manusia didasarkan pada pendekatan dengan cara menempatkan Allah melalui ketentuan syariatnya sebagai tolak ukur tentang baik buruk tatanan kehidupan manusia baik sebagai pribadi maupun sebagai masyarakat.

Dengan demikian konsep Islam tentang HAM bertumpu pada ajaran tauhid. Konsep tauhid mengandung ide persamaan dan persaudaraan manusia. Konsep tauhid juga mencakup ide persamaan dan persatuan semua makhluk. Islam datang berhubungan erat membawa ajaran tentang HAM, ajaran Islam tentang HAM dapat dijumpai dalam sumber utama ajaran Islam yaitu Al-Quran dan hadits yang merupakan sumber ajaran normatif, juga terdapat praktek kehidupan umat Islam.

Pengesahan Undang-undang terhadap perjanjian antar negara atau hukum internasional menimbulkan kewajiban bagi negara untuk menjamin perlindungan terhadap hak-hak anak, yang sekaligus merupakan HAM yang perlu dilindungi oleh hukum bahkan sejak anak masih dalam kandungan. Undang-Undang No. 39 Tahun 1999 tentang HAM mengatur bahwa setiap anak;

Pertama, berhak atas dasar perlindungan oleh orang tua, keluarga, masyarakat, dan Negara (Pasal 52); Kedua, sejak dalam kandungan berhak untuk hidup, mempertahankan hidup dan meningkatkan taraf kehidupannya dan sejak kelahirannya berhak atas suatu nama dan status kewarganegaraan (pasal 53); Ketiga, setiap anak cacat fisik dan atau mental berhak memperoleh perawatan, pendidikan, pelatihan, dan bantuan khusus atas biaya Negara untuk menjamin kehidupannya sesuai dengan martabat kemanusiaan, peningkatan rasa percaya diri dan kemampuan berpartisipasi dalam kehidupan bermasyarakat, berbangsa dan bernegara (Pasal 54);

Keempat, berhak beribadat menurut agamanya, berpikir dan berekspresi sesuai dengan tingkat intelektualitas dan usianya di bawah bimbingan orang tua dan atau wali (Pasal 55); Kelima, berhak mengetahui siapa orang tuanya, dibesarkan dan diasuh oleh orang tuanya sendiri, dalam hal orang tua anak tidak mampu membesarkan dan memelihara anaknya dengan baik dan sesuai dengan undang-undang ini. Maka anak tersebut boleh diasuh atau diangkat sebagai anak oleh orang tua sesuai dengan ketentuan peraturan perundang-undangan (Pasal 56); Keenam, Berhak dibesarkan, dipelihara, dirawat, dididik, diarahkan, dan dibimbing kehidupannya oleh orang tua atau walinya sampai dewasa sesuai dengan peraturan perundang-undangan, juga berhak mendapatkan orang tua angkat atau wali berdasarkan putusan pengadilan apabila kedua orang tua meninggal dunia atau karena sebab yang sah tidak dapat menjalankan kewajibannya sebagai orang tua sesungguhnya (Pasal 59); Ketujuh, 
berhak mendapatkan perlindungan hukum dari segala bentuk kekerasan fisik dan mental, penelantaran, perlakuan buruk, dan pelecehan seksual termasuk pemerkosaan dan atau pembunuhan terhadap anak yang seharusnya dilindungi, maka harus dikenakan pemerataan hukuman (pasal 58);

Kedelapan, berhak tidak dipisahkan dari orang tuanya secara bertentangan dengan kehendak anak sendiri, kecuali jika ada alasan dan aturan hukum yang sah yang menunjukkan bahwa pemisahan itu adalah demi kepentingan terbaik bagi anakanak tetap berhak untuk tetap bertemu langsung dan berhubungan pribadi secara tetap dengan orang tuanya tetap dijamin oleh undang-undang (Pasal 59); Kesembilan, berhak memperoleh pendidikan dan pengajaran dalam rangka pengembangan pribadinya sesuai dengan minat, bakat, dan tingkat kecerdasannya, dan berhak mencari, menerima, dan memberikan informasi sesuai dengan tingkat intelektualitas dan usianya demi pengembangan dirinya sepanjang sesuai dengan nilai-nilai kesusilaan dan kepatutan (Pasal 60);

Kesepuluh, berhak beristirahat, bergaul dengan anak yang sebaya, bermain, berekreasi, dan berkreasi sesuai dengan minat, bakat, dan tingkat kecerdasannya demi pengembangan diri (Pasal 61); Kesebelas, berhak memperoleh pelayanan kesehatan dan jaminan sosial secara layak, sesuai kebutuhan fisik dan mental spiritualnya (Pasal 62); Keduabelas, berhak tidak dilibatkan di dalam peristiwa peperangan, sengketa bersenjata, kerusuhan sosial dan peristiwa lain yang mengandung unsur kekerasan (Pasal 63); Ketigabelas, berhak memperoleh perlindungan dari kegiatan eksploitasi ekonomi dan setiap pekerjaan yang membahayakan dirinya, sehingga dapat mengganggu pendidikan, kesehatan fisik, moral, kehidupan sosial, dan mental spritualnya (Pasal 64);

Keempatbelas, berhak memperoleh perlindungan dari kegiatan eksploitasi dan pelecehan seksual, penculikan, perdagangan anak, serta dari berbagai bentuk penyalahgunaan narkotik, psikotropika dan zat aditif lainnya (Pasal 65); Kelimabelas, berhak tidak dijadikan sasaran penganiayaan, penyiksaan atau penjatuhan hukuman yang tidak manusiawi (Pasal 66).

\section{Analisis Penelantaran Anak Ditinjau dalam Hukum Islam dan HAM}

Penelantaran anak dalam hal apapun merupakan perbuatan yang dilarang baik secara hukum Islam dan hukum positif yang berlaku. Dijelaskan dalam QS. At Tahrim ayat 6, bahwa diri dan keluarga harus dipelihara terlebih untuk anak yang menjadi generasi penerus di masa depan. Sebagai orang tua harus mendidik, memberi kasih sayang, perhatian dan mengayomi agar anak dapat memajukan dan memperjuangkan agama dan bangsa dengan baik bukan malah menelantarkannya.

Undang-Undang No. 39 Tahun 1999 tentang HAM mengatur bahwa setiap anak berhak atas dasar perlindungan oleh orang tua, keluarga, masyarakat, dan negara. Sejak dalam kandungan berhak untuk hidup, mempertahankan hidup dan meningkatkan taraf kehidupannya dan sejak kelahirannya berhak atas suatu nama dan status kewarganegaraan. 
Setiap manusia individu maupun kelompok berhak juga atas pelindungan hukum, pendidikan dan pengajaran terlebih untuk anak-anak. Oleh sebab itu, perhatian ekstra yang harus diberikan kepada anak-anak sehingga tumbuh kembang anak baik. Dampak yang ditimbulkan atau yang dialami oleh anak terlantar adalah fisik, psikologis dan sosialnya.

Dampak fisik sangat berpengaruh terhadap penampilan anak, yang paling signifikan adalah anak tumbuh dan berkembang tidak sesuai dengan usianya artinya anak tersebut melaksanakan atau melakukan suatu aktivitas tidak sesuai dengan kondisi tubuhnya. Selain itu, dampak fisik dari penelantaran adalah anak tidak tercukupinya kebutuhannya baik kebutuhan pokoknya.

Dampak psikologis anak yang mengalami gangguan psikologis disebabkan oleh perlakuan salah ataupun tindakan yang diterima dari orang lain sehingga menyebabkan mereka menjadi pribadi yang tidak berani untuk menyampaikan atau mengucapkan yang mereka rasakan atau inginkan. Anak yang kurang mendapatkan perhatian dari orang tua juga menyebabkan hal yang tidak baik bagi psikologisnya sehingga harus benar-benar diseriusi masalah perhatian terhadap anak.

Kemudian dampak sosial merupakan bagian yang tidak terpisahkan dalam kehidupan di lingkungan sosialnya di mana anak-anak mendapatkan perlindungan sosial dalam lingkungan keluarga dan lingkungan sekitarnya. Akibat yang sering terjadi dari faktor sosial anak adalah berpisahnya orang tua antara ayah dan ibu, sehingga anak terabaikan tidak mendapatkan kasih sayang dari kedua orang tua.

\section{KESIMPULAN}

Dalam kajian hukum Islam fenomena penelantaran masih banyak terjadi dalam kehidupan masyarakat, itu terjadi karena faktor ketidakpedulian terhadap anak. Bentuk apapun dalam penelantaran adalah hal yang dilarang baik itu secara agama maupun secara hukum yang berlaku di Negara. Dalam QS. At Tahrim ayat 6 dan QS. An-Nisa ayat 9 menjelaskan pentingnya keluarga yang harus dijaga baik-baik. Sudah sangat jelas dalam hukum Islam bahwa Islam sangat melarang penelantaran anak. Sehingga perkembangan fisik dan emosional pun menjadi tidak normal, anak mengalami gangguan bahasa dan sosial, tidak tegas, sering bolos sekolah serta penampilannya tidak terawat.

Tinjauan HAM terhadap penelantaran anak merupakan salah satu bentuk perlakuan terburuk dan tindakan kekerasan yang dialami oleh anak dan ini merupakan pelanggaran HAM terhadap anak. Bentuk perlindungan secara hukum oleh negara kepada anak tertera pada Undang-Undang Nomor 39 Tahun 1999 tentang Hak Asasi Manusia. Di samping perlidungan dari negara, hal yang tidak kalah pentingnya adalah peran orang tua dan masyarakat dalam membentuk mental dan moral anak. Bimbingan dari orang tua dan dukungan dari lingkungan masyarakat untuk mengenalkan perbuatan baik dan perbuatan buruk atau menyimpang serta akibat setiap perbuatan tersebut kepada anak diharapkan dapat membentuk mental dan moral anak menjadi lebih baik sehingga anak mampu menjaga dirinya dari 
pengaruh-pengaruh negatif lingkungan yang mungkin membentuk perilaku yang buruk pada diri anak.

\section{REFERENSI:}

Aji, A.M.; Yunus, N.R. Basic Theory of Law and Justice, Jakarta: Jurisprudence Institute, 2018.

Bank Data, Rincian Data Kasus Berdasarkan Klaster Perlindungan Anak, 2011-2016 https://bankdata.kpai.go.id/tabulasi-data/data-kasus-per-tahun/rincian-datakasus-berdasarkan-klaster-perlindungan-anak-2011-2016 [20 Jan 2020].

Divianta, D. Akhir Tragis 'Adopsi' Bocah Cantik Angeline,

Effendi, M. 1994. Dimensi dan Dinamika Hak Asasi Manusia dalam Hukum Nasional dan Internasiona. Jakarta: Ghalia Indonesia.

Hamid, M. A. 2011. Hukum Islam Perspektif Keindonesiaan (Sebuah Pengantar Dalam Memahami Realitasnya di Indonesia). Makasar: PT. Umitoha Ukhuwah Grafika.

Https://www.liputan6.com/news/read/2398135/5-kisah-anak-korban-kekerasan-palingmemilukan-sepanjang-2015.

https://www.liputan6.com/regional/read/2446513/akhir-tragis-adopsi-bocahcantik-angeline [25 Feb 2020]

Huraerah, Abu. 2006. Kekerasan Anak Terhadap Anak. Bandung: Nuansa.

Maggalatung, A.S.; Aji, A.M.; Yunus, N.R. How The Law Works, Jakarta: Jurisprudence Institute, 2014.

Mutiah, D. 2015. 5 Kisah Anak Korban Kekerasan Paling Memilukan Sepanjang 2015, https://www.liputan6.com/news/read/2398135/5-kisah-anak-korban-kekerasanpaling-memilukan-sepanjang-2015 [20 Feb 2020].

Nusantara, Abdul hakim Garuda. 1986. Prospek Perlindungan Anak. Makalah. Jakarta: Seminar Perlindungan Hak-hak Anak.

Riyaldi, E. 2018. Hukum Hak Asasi Manusia Perspektif Internasional Regional dan Nasional . Depok: Rajawali Pers.

Shomad. (2012). Hukum Islam Penormaan Prinsip Syari'ah Dalam Hukum Indonesia. Jakarta: Prenada Media Group.

Tholib, S. 2010. Pokok-pokok Hukum Penitensier Indonesia. Bandung: Alfabeta.

Wibawanto, A. 1999. Jalan Kemanusian: Panduan untuk Memperkuat Hak Asasi Manusia. Yogyakarta: Lapera Pustaka Utama.

Yanggo, H. T. 2010. Fiqih Perempuan Kontemporer. Bandung: PT. Ghalia Indonesia.

Yunus, N.R.; Anggraeni, RR Dewi.; Rezki, Annissa. "The Application of Legal Policy

Theory and its relationship with Rechtsidee Theory to realize Welfare State,"

'Adalah, Volume 3, No. 1 (2019) 